\title{
A Novel Electrochromic Polymer Synthesized through Electropolymerization of a New Donor-Acceptor Bipolar System
}

\author{
Jose Natera, Luis Otero, Leonides Sereno, and Fernando Fungo* \\ Departamento de Química, Universidad Nacional de Río Cuarto, \\ Agencia Postal 3 (5800), Río Cuarto, Argentina \\ Nung-Sen Wang, Yeun-Min Tsai, Tsyr-Yuan Hwu, and Ken-Tsung Wong* \\ Department of Chemistry, National Taiwan University, Taipei 106, Taiwan
}

Received January 8, 2007; Revised Manuscript Received April 18, 2007

\begin{abstract}
We have synthesized a novel 9,9'-spirobifluorene-cored donor-acceptor (D-A) bichromophore system in which the electron-donating (D) moieties are triphenylamine (TPA) and carbazole (CBZ) groups and the electron-withdrawing (A) moieties are 1,3,4-oxadiazole (OXD) groups. The electron-deficient OXD groups efficiently blocked the radical cations delocalization between the two terminal TPA groups, rendering the electropolymerization of the TPA groups feasible. The resulting polymer could be cross-linked further at higher oxidation potentials through electrodimerization occurring at the $\mathrm{C} 3$ and $\mathrm{C} 6$ positions of the $\mathrm{CBZ}$ group. The polymer film obtained exhibited reversible electrochemical oxidation, accompanied by strong color changes with high coloration efficiency and contrast ratio, which could be switched through potential modulation.
\end{abstract}

\section{Introduction}

The search for new polymeric and oligomeric materials for application in thin film optoelectronic devices, such as organic light-emitting diodes (OLEDs), solar cells, electrochromic cells, and organic field effect transistors (OTFTs), ${ }^{1-5}$ is one of the most active areas in contemporary materials science. Although these devices perform various functions, common problems associated with charge transportation phenomena are key issues challenging the development of efficient optoelectronic devices. Thin films exhibiting high conductivity or photoconductivity that are fabricated through the electropolymerization of electroactive monomers are potential alternative materials for the preparation of highly efficient devices. The use of electrogenerated films has the advantage of one-step polymer synthesis, which allows fine control over the film thickness-an important parameter when fabricating optoelectronic devices. With the objective of obtaining a system displaying good charge transport ability, enhanced optoelectronic properties, and facile electropolymerization, we designed a novel donor-acceptor (D-A) system composed of two D-A segments (1, Scheme 1), in which $9,9^{\prime}$-spirobifluorene was introduced as a rigid core and linker to provide sufficient morphological and thermal stability of the resulting films. ${ }^{6,9}$ In $\mathbf{1}$, the electron-donating triphenylamine moieties (TPA) are separated by two electron-withdrawing 1,3,4-oxadiazole (OXD) groups, which are grafted in a meta configuration onto a phenylene ring then attached to the rigid spirobifluorene core. A second electron-rich moiety, carbazole (CBZ), was introduced onto the central skeleton to serve as a potentially electropolymerizable site. Upon oxidation, we expected 1 to undergo the well-known radical cation dimerization of the TPA moieties to produce tetraphenylbenzidine (TPB). ${ }^{10-16}$ In general, the TPA dimerization reaction does not extend into a polymerization process because of the relatively higher stability of TPB radical cation. ${ }^{10}$ The introduction of a nonconjugated spacer ${ }^{16}$ or an electron-deficient group ${ }^{15,17}$ - such

* Corresponding authors. E-mail: ffungo@exa.unrc.edu.ar; kenwong@ ntu.edu.tw. as OXD-between the two TPA groups, however, increases the dimerization reactivity of the TPA radical cation, allowing individual TPA to realize an independent coupling reaction and rendering the electropolymerization process feasible. In addition to the polymer formed through TPA dimerization of $\mathbf{1}$, we expected that the presence of a second oxidizable group, the CBZ moiety, would allow efficient cross-linkage during the electropolymerization because of the recognized capability of $\mathrm{CBZ}$ to form electrogenerated dimers. ${ }^{18-20} \mathrm{CBZ}$ dimers and polymers usually exhibit high electrical conductivity and good optical quality, giving them great potential for use in optoelectronic applications. ${ }^{21-24}$ Considering the electron-deficient nature of the OXD groups and electron-rich character of the TPA and CBZ groups, we consider 1 to be a $\mathrm{D}-\mathrm{A}$ type chromophore and anticipated that it would exhibit charge-transfer emissive states.

\section{Experimental Section}

Synthesis. 2-Bromo-7-(carbazol-9-yl)-9,9'-spirobifluorene (3). An oven-dried resealable Schlenk tube charged with $\mathrm{CuI}(0.18 \mathrm{~g}$, $0.9 \mathrm{mmol})$, carbazole $(1.0 \mathrm{~g}, 5.98 \mathrm{mmol}), \mathrm{K}_{3} \mathrm{PO}_{4}(2.8 \mathrm{~g}, 12.55$ $\mathrm{mmol}$ ), and 2,7-dibromo-9,9'-spirobifluorene (5.6 g, $11.96 \mathrm{mmol}$ ) was evacuated and backfilled with Ar. Dry toluene $(20 \mathrm{~mL})$ and dry trans-1,2-cyclohexanediamine $(0.42 \mathrm{~mL}, 3.6 \mathrm{mmol})$ were then added under Ar. The Schlenk tube was sealed with a Teflon valve, and the mixture stirred magnetically at $120{ }^{\circ} \mathrm{C}$ for $48 \mathrm{~h}$. The resulting suspension was cooled to room temperature and filtered through a pad of silica gel, eluting with ethyl acetate. The filtrate was concentrated, and the residue was purified through flash chromatography on silica gel (hexane/dichloromethane, 95:5) to afford 3 as a white solid $(1.8 \mathrm{~g}, 54 \%)$; $\mathrm{mp} 316-317^{\circ} \mathrm{C}$. IR (neat): $v$ 3055, 1613, 1501, 1448, 1245, 1143, $811 \mathrm{~cm}^{-1} .{ }^{1} \mathrm{H} \mathrm{NMR}\left(\mathrm{CDCl}_{3}\right.$, $400 \mathrm{MHz}): \delta 6.84(\mathrm{~d}, J=7.5 \mathrm{~Hz}, 2 \mathrm{H}), 6.88[\mathrm{~s}, 1 \mathrm{H}, \mathrm{C}(1)-\mathrm{H}]$, $6.90[\mathrm{~s}, 1 \mathrm{H}, \mathrm{C}(8)-\mathrm{H}], 7.14-7.20(\mathrm{~m}, 6 \mathrm{H}), 7.26(\mathrm{t}, J=7.5 \mathrm{~Hz}$, $2 \mathrm{H}), 7.36(\mathrm{t}, J=7.5 \mathrm{~Hz}, 2 \mathrm{H}), 7.55(\mathrm{ddd}, J=10,7.5,2 \mathrm{~Hz}, 2 \mathrm{H})$, $7.76(\mathrm{~d}, J=10 \mathrm{~Hz}, 1 \mathrm{H}), 7.78(\mathrm{~d}, J=7.5 \mathrm{~Hz}, 2 \mathrm{H}), 7.99$ (d, $J=7.5$ $\mathrm{Hz}, 1 \mathrm{H}), 8.02(\mathrm{~d}, J=7.5 \mathrm{~Hz}, 2 \mathrm{H}) .{ }^{13} \mathrm{C} \mathrm{NMR}\left(\mathrm{CDCl}_{3}, 100 \mathrm{MHz}\right)$ : $\delta 65.9,109.5,119.8,120.1,120.2,121.1,121.4,121.7,122.6,123.8$, $123.9,125.7,126.5,127.4,127.9,128.1,131.1,137.3,139.5,139.8$, 140.4, 141.6, 147.2, 150.5, 150.9. FAB MS $m / z$ (rel intensity): 561 
Scheme 1. Synthesis of the Novel D-A Molecule 1 and Structure of the Model Compound 9

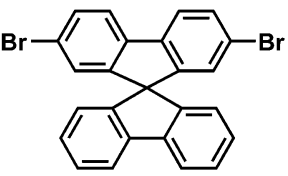

2

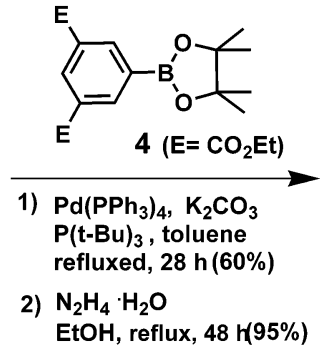

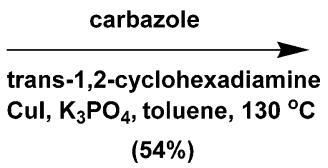

(54\%)

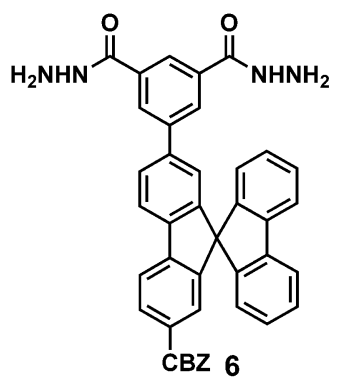

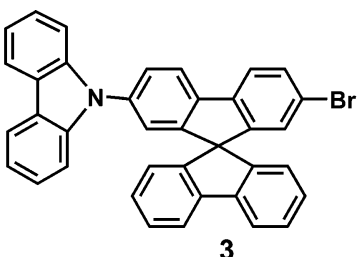

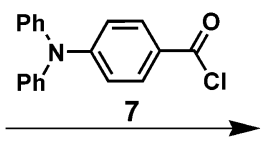

$E t_{3} N, N M P, 120^{\circ} \mathrm{C}$

(74\%)

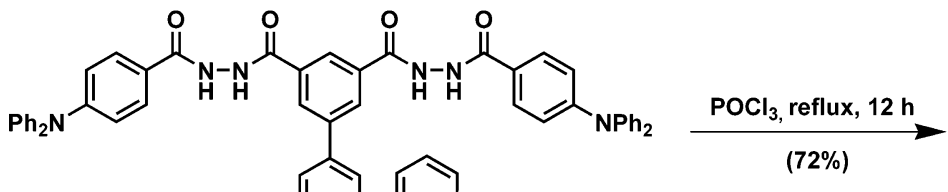<smiles>C[C-](C)c1ccc2c(c1)C1(c3ccccc3-c3ccccc31)c1ccccc1-2</smiles><smiles>CN(C)c1ccc(-c2nnc(-c3cc(-c4ccc5c(c4)C4(c6ccccc6-5)c5ccccc5-c5ccc(N(C)C)cc54)cc(-c4nnc(-c5ccc(N)c(F)c5)o4)c3)o2)cc1</smiles>

$\left(\mathrm{M}^{+}, 1\right), 307$ (35), 154 (100), 136 (63). HRMS (FAB) calcd for $\mathrm{C}_{37} \mathrm{H}_{22} \mathrm{~N}^{79} \mathrm{Br}$ 559.0936, found 559.0928; calcd for $\mathrm{C}_{37} \mathrm{H}_{22} \mathrm{~N}^{81} \mathrm{Br}$ 561.0915 , found 561.0920 .

5-(4,4,5,5-Tetramethyl-1,3,2-dioxaborolan-2-yl)-1,3-benzenedicarboxylic Acid Dimethyl Ester (4). Degassed dry DMF (18 $\mathrm{mL}$ ) was added to a mixture of 5-bromo-1,3-benzenedicarboxylic acid dimethyl ester ( $2.0 \mathrm{~g}, 8.0 \mathrm{mmol})$, bis(pinacolato)diboron (2.03 $\mathrm{g}, 8.0 \mathrm{mmol})$, potassium acetate $(2.2 \mathrm{~g}, 24 \mathrm{mmol})$, and $\mathrm{Pd}(\mathrm{OAc})_{2}$ (49 mg, $0.22 \mathrm{mmol}$ ). The mixture was heated to $90{ }^{\circ} \mathrm{C}$ (oil bath) for $24 \mathrm{~h}$. After cooling to room temperature, the solution was added dropwise to water $(90 \mathrm{~mL})$ and stirred vigorously for $10 \mathrm{~min}$. The solid was collected by filtration and purified through column chromatography on silica gel (hexane/ethyl acetate, 95:5) to afford 4 as a white solid (2.01 g, 86\%); mp $126-127{ }^{\circ} \mathrm{C}$. IR (neat): $v$ 2986, 2959, $1726(\mathrm{C}=\mathrm{O}), 1613,1388,1249,1136 \mathrm{~cm}^{-1}$. ${ }^{1} \mathrm{H}$ NMR $\left(\mathrm{CDCl}_{3}, 400 \mathrm{MHz}\right): \delta 1.35$ (s, 12H, Me), 3.93 (s, 6H, OMe), 8.61 $[\mathrm{s}, 2 \mathrm{H}, \mathrm{C}(3)-\mathrm{H}], 8.74[\mathrm{~s}, 1 \mathrm{H}, \mathrm{C}(2)-\mathrm{H}] .{ }^{13} \mathrm{C}$ NMR $\left(\mathrm{CDCl}_{3}, 100\right.$ $\mathrm{MHz}): \delta 25.0,52.3,84.4,130.0,133.2,140.0,166.1 . \mathrm{FAB}$ MS $\mathrm{m} / \mathrm{z}$ (rel intensity): $320\left(\mathrm{M}^{+}, 1\right), 305$ (26), 277 (100), 221 (58), 178 , (35), 84 (50). HRMS (EI) calcd for $\mathrm{C}_{16} \mathrm{H}_{21} \mathrm{BO}_{6} 320.1431$, found 320.1430. Anal. calcd for $\mathrm{C}_{16} \mathrm{H}_{21} \mathrm{BO}_{6} \mathrm{C}, 60.03 ; \mathrm{H}, 6.61$, found $\mathrm{C}$, $60.59 ; \mathrm{H}, 6.71$.

2-(Carbazol-9-yl)-7-(3,5-bismethoxycarbonyl)phenyl-9,9' -spirobifluorene (5). $\mathrm{Pd}\left(\mathrm{PPh}_{3}\right)_{4}(21 \mathrm{mg}, 0.018 \mathrm{mmol})$ and $t-\mathrm{Bu}_{3} \mathrm{P}(0.05$
$\mathrm{M}$ in toluene, $0.72 \mathrm{~mL}, 0.036 \mathrm{mmol}$ ) were added in one portion to a degassed mixture of bromide $3(0.1 \mathrm{~g}, 0.18 \mathrm{mmol})$, borane 4 (58 $\mathrm{mg}, 0.18 \mathrm{mmol})$, aqueous $\mathrm{K}_{2} \mathrm{CO}_{3}(0.18 \mathrm{~mL}, 2.0 \mathrm{M})$, and toluene $(9$ $\mathrm{mL})$. Under Ar, the resulting mixture was heated under reflux for $28 \mathrm{~h}$. After cooling to room temperature, the solution was quenched with brine $(50 \mathrm{~mL})$ and $\mathrm{CHCl}_{3}(70 \mathrm{~mL})$. The organic layer was dried $\left(\mathrm{MgSO}_{4}\right)$ and concentrated. The crude product was purified through column chromatography on silica gel (hexane/ethyl acetate, 9:1) to afford 5 as a yellow solid $(72 \mathrm{mg}, 60 \%)$; mp 305-306 ${ }^{\circ} \mathrm{C}$. IR (neat): $v$ 3052, 2959, $1726(\mathrm{C}=\mathrm{O}), 1600,1441 \mathrm{~cm}^{-1} .{ }^{1} \mathrm{H}$ NMR $\left(\mathrm{CDCl}_{3}, 400 \mathrm{MHz}\right): \delta 3.92\left(\mathrm{~s}, 6 \mathrm{H}, \mathrm{OCH}_{3}\right), 6.89-6.91(\mathrm{~m}, 3 \mathrm{H})$, $7.08(\mathrm{~s}, 1 \mathrm{H}), 7.16-7.22(\mathrm{~m}, 6 \mathrm{H}), 7.29(\mathrm{t}, J=7.5 \mathrm{~Hz}, 2 \mathrm{H}), 7.38(\mathrm{t}$, $J=7.5 \mathrm{~Hz}, 2 \mathrm{H}), 7.59(\mathrm{~d}, J=7.5 \mathrm{~Hz}, 1 \mathrm{H}), 7.75(\mathrm{~d}, J=7.5 \mathrm{~Hz}$, $1 \mathrm{H}), 7.82(\mathrm{~d}, J=7.5 \mathrm{~Hz}, 2 \mathrm{H}), 8.02(\mathrm{~d}, J=7.5 \mathrm{~Hz}, 1 \mathrm{H}), 8.05(\mathrm{~d}$, $J=7.5 \mathrm{~Hz}, 2 \mathrm{H}), 8.08(\mathrm{~d}, J=7.5 \mathrm{~Hz}, 1 \mathrm{H}), 8.32(\mathrm{~s}, 2 \mathrm{H}), 8.56(\mathrm{~s}$, 1H). ${ }^{13} \mathrm{C} \mathrm{NMR}\left(\mathrm{CDCl}_{3}, 100 \mathrm{MHz}\right): \delta 52.5,66.1,109.5,119.7$, $120.1,120.2,120.6,121.2,122.5,122.8,123.2,123.8,125.7,126.3$, $127.3,127.9,128.0,129.1,130.9,132.1,137.2,138.8,139.7,140.4$, 141.1, 141.5, 141.7, 147.6, 149.8, 151.4, 166.0. FAB MS $\mathrm{m} / \mathrm{z}$ (rel intensity): $673\left(\mathrm{M}^{+}, 56\right), 507$ (10), 368 (16), 256 (13), 185 (16), 129 (29), 55 (100). HRMS (FAB) calcd for $\mathrm{C}_{47} \mathrm{H}_{31} \mathrm{NO}_{4} 673.2253$, found 673.2259. Anal. Calcd for $\mathrm{C}_{47} \mathrm{H}_{31} \mathrm{NO}_{4} \cdot \mathrm{H}_{2} \mathrm{O}$ : C, 81.59; $\mathrm{H}$, 4.81 ; N, 2.03. Found: C, 81.38; H, 4.81; N, 2.03. 
2-(Carbazol-9-yl)-7-(3,5-dihydrazinocarbonyl)phenyl-9,9' spirobifluorene (6). Hydrazine monohydrate $(0.3 \mathrm{~mL}, 6.0 \mathrm{mmol})$ was added to a solution of diester $5(0.2 \mathrm{~g}, 0.30 \mathrm{mmol})$ in EtOH (5 $\mathrm{mL}$ ), and then the mixture was heated under reflux under Ar for $48 \mathrm{~h}$. After cooling to room temperature, the solid was collected by filtration, washed with methanol, and dried in vacuo to give 6 as a white solid $(0.18 \mathrm{~g}, 95 \%) ; \mathrm{mp} 341-342{ }^{\circ} \mathrm{C}$. IR (neat): $v 3314$ (NH), 3057, 3013, $1709(\mathrm{C}=\mathrm{O}), 1635,1613,1459 \mathrm{~cm}^{-1} .{ }^{1} \mathrm{H}$ NMR (DMSO- $d_{6}, 400 \mathrm{MHz}$ ): $\delta 4.51$ (br s, $4 \mathrm{H}, \mathrm{NH}_{2}$ ), 6.65 (s, 1H), 6.85 $(\mathrm{d}, J=7.5 \mathrm{~Hz}, 2 \mathrm{H}), 7.09(\mathrm{~d}, J=7.5 \mathrm{~Hz}, 2 \mathrm{H}), 7.15(\mathrm{~s}, 1 \mathrm{H}), 7.18-$ $7.23(\mathrm{~m}, 4 \mathrm{H}), 7.30(\mathrm{t}, J=7.5 \mathrm{~Hz}, 2 \mathrm{H}), 7.42(\mathrm{t}, J=7.5 \mathrm{~Hz}, 2 \mathrm{H})$, $7.69(\mathrm{~d}, J=7.5 \mathrm{~Hz}, 1 \mathrm{H}), 7.96-8.00(\mathrm{~m}, 5 \mathrm{H}), 8.14-8.16(\mathrm{~m}, 3 \mathrm{H})$, $8.31(\mathrm{~d}, J=7.5 \mathrm{~Hz}, 1 \mathrm{H}), 8.38(\mathrm{~d}, J=7.5 \mathrm{~Hz}, 1 \mathrm{H}), 9.91(\mathrm{~s}, 2 \mathrm{H}$, NH). ${ }^{13} \mathrm{C}$ NMR (DMSO- $d_{6}, 100 \mathrm{MHz}$ ): $\delta 66.4,109.8,120.8,121.2$, $121.5,121.7,122.3,122.5,123.2,123.3,124.1,126.1,126.8,127.1$, 127.8, 128.2, 128.9, 134.9, 137.0, 139.6, 140.3, 140.4, 141.4, 141.9, 148.1, 149.9, 151.6, 165.8. FAB MS m/z (rel intensity): $673\left(\mathrm{M}^{+}\right.$, 3), 613 (3), 460 (15), 307 (100), 289 (45). HRMS (FAB) calcd for $\mathrm{C}_{45} \mathrm{H}_{31} \mathrm{~N}_{5} \mathrm{O}_{2}$ 673.2478, found 673.2485 .

4-Diphenylaminobenzoic Acid. ${ }^{25}$ A mixture of 4-(diphenylamino)benzonitrile ( $0.9 \mathrm{~g}, 3.33 \mathrm{mmol}), 20 \%$ aqueous $\mathrm{NaOH}(27 \mathrm{~mL})$, and $\mathrm{EtOH}(9 \mathrm{~mL})$ was heated under reflux overnight. After cooling to room temperature, the solution was acidified with $3 \mathrm{~N}$ hydrochloric acid $(60 \mathrm{~mL})$ and then stirred vigorously for $10 \mathrm{~min}$. The solid was collected by filtration; the filter cake was washed with water and dried in vacuo to give 4-diphenylaminobenzoic acid as a white solid $(0.95 \mathrm{~g}, 99 \%) .{ }^{1} \mathrm{H} \mathrm{NMR}\left(\mathrm{CDCl}_{3}, 400 \mathrm{MHz}\right): \delta 6.97$ $(\mathrm{d}, J=7.5 \mathrm{~Hz}, 2 \mathrm{H}), 7.10-7.15(\mathrm{~m}, 6 \mathrm{H}), 7.30(\mathrm{t}, J=7.5 \mathrm{~Hz}, 4 \mathrm{H})$, $7.88(\mathrm{~d}, J=7.5 \mathrm{~Hz}, 2 \mathrm{H}) .{ }^{13} \mathrm{C} \mathrm{NMR}\left(\mathrm{CDCl}_{3}, 100 \mathrm{MHz}\right): \delta 119.4$, 120.7, 124.6, 125.9, 129.5, 131.4, 146.3, 152.5, 170.8 .

7-[3,5-Bis(4-diphenylaminobenzoylhydrazinocarbonyl)phenyl]2-(carbazol-9-yl)-9,9'-spirobifluorene (8). Oxalyl chloride $(0.27$ $\mathrm{mL}, 3.09 \mathrm{mmol})$ and dry DMF $(10 \mu \mathrm{L})$ were added at room temperature to a solution of 4-diphenylaminobenzoic acid $(0.3 \mathrm{~g}$, $1.03 \mathrm{mmol})$ in dry $\mathrm{CH}_{2} \mathrm{Cl}_{2}(5 \mathrm{~mL})$. The solution was stirred for 30 min and then concentrated in vacuo to give the acid chloride $\mathbf{7}$ as yellow oil $(0.3 \mathrm{~g}, 94 \%)$. Dry $\mathrm{Et}_{3} \mathrm{~N}(0.15 \mathrm{~mL}, 1.03 \mathrm{mmol})$ was added under Ar to a solution of dihydazide $6(0.30 \mathrm{~g}, 0.47 \mathrm{mmol})$ in dry NMP $(3 \mathrm{~mL})$. The resulting mixture was gently heated to $120^{\circ} \mathrm{C}$ (oil bath), and then a solution of 7 in dry NMP $(6 \mathrm{~mL})$ was added in one portion under Ar. The mixture was stirred for $48 \mathrm{~h}$. After cooling to room temperature, the solution was added dropwise to water $(90 \mathrm{~mL})$ with vigorous stirring. The solid was collected by filtration and recrystallized (hexane/THF) to afford $\mathbf{8}$ as a white solid (0.42 g, 74\%); mp 208-209 ${ }^{\circ} \mathrm{C}$. IR (neat): $v 3251(\mathrm{NH})$, 3052, $1659(\mathrm{C}=\mathrm{O}), 1600,1501,1454,1269 \mathrm{~cm}^{-1} .{ }^{1} \mathrm{H}$ NMR (DMSO- $\left.d_{6}, 400 \mathrm{MHz}\right): \delta 6.66(\mathrm{~s}, 1 \mathrm{H}), 6.75-6.80(\mathrm{~m}, 2 \mathrm{H}), 6.87$ $(\mathrm{d}, J=7.5 \mathrm{~Hz}, 2 \mathrm{H}), 6.93(\mathrm{~d}, J=7.5 \mathrm{~Hz}, 4 \mathrm{H}), 7.04-7.43(\mathrm{~m}$, $28 \mathrm{H}), 7.55(\mathrm{~d}, J=7.5 \mathrm{~Hz}, 1 \mathrm{H}), 7.70(\mathrm{~d}, J=7.5 \mathrm{~Hz}, 1 \mathrm{H}), 7.80(\mathrm{~d}$, $J=7.5 \mathrm{~Hz}, 4 \mathrm{H}), 7.96-8.00(\mathrm{~m}, 2 \mathrm{H}), 8.04(\mathrm{~d}, J=7.5 \mathrm{~Hz}, 1 \mathrm{H})$, $8.15(\mathrm{~d}, J=7.5 \mathrm{~Hz}, 2 \mathrm{H}), 8.19(\mathrm{~s}, 2 \mathrm{H}), 8.33-8.41(\mathrm{~m}, 3 \mathrm{H}), 10.34$ (s, 2H), 10.68 (s, 2H). ${ }^{13} \mathrm{C}$ NMR (DMSO- $\left.d_{6}, 100 \mathrm{MHz}\right): \delta 66.5$, 100.3, 109.9, 120.6, 120.8, 121.3, 121.6, 121.7, 122.5, 123.4, 124.1, $125.1,125.3,125.5,126.0,126.4,126.8,129.0,129.6,130.5,131.2$ 134.5, 137.1, 139.4, 140.3, 140.4, 140.7, 141.6, 142.0, 146.5, 146.9, $148.1,150.0,151.1,151.6,160.4,165.8$. FAB MS $\mathrm{m} / \mathrm{z}$ (rel intensity): $1216\left(\mathrm{M}^{+}, 3\right), 945$ (1), 460 (10), 307 (50), 272 (100), $242(10)$.

7-\{3,5-Bis[5-(4-diphenylaminophenyl)-1,3,4-oxadiazol-2-yl]phenyl \}-2-(carbazol-9-yl)-9,9'-spirobifluorene (1). A mixture of $8(0.20 \mathrm{~g}, 0.16 \mathrm{mmol})$ and $\mathrm{POCl}_{3}(10 \mathrm{~mL})$ was heated under reflux under Ar for $12 \mathrm{~h}$. After cooling to room temperature, the solution was added dropwise to ice water $(100 \mathrm{~mL})$ and then stirred vigorously for $10 \mathrm{~min}$. The solid was collected by filtration; the filter cake was washed with water and purified through column chromatography on silica gel (hexane/ethyl acetate, 1/1) to afford $\mathbf{1}$ as a yellow solid $(0.13 \mathrm{~g}, 72 \%)$; mp $215-218^{\circ} \mathrm{C}, T_{\mathrm{g}} 195^{\circ} \mathrm{C}$. IR (neat): $v$ 3065, 1620, 1587, $1269 \mathrm{~cm}^{-1} .{ }^{1} \mathrm{H} \mathrm{NMR}\left(\mathrm{CDCl}_{3}, 400\right.$ MHz): $\delta 6.89-6.91$ [two overlapping doublets at $6.90(J=7 \mathrm{~Hz})$ and $6.91(J=2 \mathrm{~Hz}) \mathrm{ppm}, 3 \mathrm{H}], 7.08-7.21(\mathrm{~m}, 23 \mathrm{H}), 7.27(\mathrm{~d}, J=$ $7 \mathrm{~Hz}, 2 \mathrm{H}), 7.30-7.37$ (m, 10H), 7.59 (dd, $J=7 \mathrm{~Hz}, 1 \mathrm{H}), 7.79-$
7.82 (two overlapping doublets at 7.80 and $7.81 \mathrm{ppm}, J=7 \mathrm{~Hz}, 3$ H), $7.93(\mathrm{~d}, J=9 \mathrm{~Hz}, 4 \mathrm{H}), 8.03(\mathrm{~d}, J=7 \mathrm{~Hz}, 3 \mathrm{H}), 8.05(\mathrm{~d}, J=$ $7 \mathrm{~Hz}, 1 \mathrm{H}), 8.09$ (d, $J=7 \mathrm{~Hz}, 1 \mathrm{H}), 8.36(\mathrm{~d}, J=1.6 \mathrm{~Hz}, 2 \mathrm{H}), 8.60$ $(\mathrm{t}, J=1.6 \mathrm{~Hz}, 1 \mathrm{H}) .{ }^{13} \mathrm{C} \mathrm{NMR}\left(\mathrm{CDCl}_{3}, 100 \mathrm{MHz}\right): \delta 66.2,109.5$, $115.4,119.8,120.1,120.3,120.7,120.8,121.3,122.5,122.9,123.2$, $123.8,124.4,125.4,125.6,125.7,126.3,127.4,127.9,128.1,129.5$, 137.3, 138.5, 139.7, 140.4, 141.4, 141.7, 142.9, 146.4, 147.5, 150.1, 151.0, 151.4, 162.8, 164.9. MS (FAB): $\mathrm{m} / \mathrm{z}$ (rel intensity) 1180 $\left(\mathrm{M}^{+}, 60\right), 894$ (10), 868 (7), 272 (100). Anal. Calcd for $\mathrm{C}_{83} \mathrm{H}_{53} \mathrm{~N}_{7} \mathrm{O}_{2}$ : C, 84.46; H, 4.53; N, 8.31. Found: C, 84.06; H, 4.54; $\mathrm{N}, 8.23$.

Electrochemical and Spectroelectrochemical Characterization. Cyclic voltammetry (CV) and spectroelectrochemical studies were performed using dichloroethane (DCE) or acetonitrile $(\mathrm{MeCN})$ as solvent; relatively nonpolar solvents, such as benzene (Ben) and hexane (Hex), were used for photophysical studies. DCE was dried over $3 \AA$ molecular sieves for $48 \mathrm{~h}$ prior to use and stored over $\mathrm{Na}_{2} \mathrm{CO}_{3}$. For the electrochemical experiments, a potentiostatgalvanostat (Autololab-Electrochemical Instrument) was employed with $0.1 \mathrm{M}$ tetrabutylammonium perchlorate (TBAP, dried for 24 $\mathrm{h}$ under vacuum prior to use) as the supporting electrolyte. The Pyrex cell, which was operated at room temperature, featured a $2.16 \times 10^{-3} \mathrm{~cm}^{2}$ inlaid Pt disk as the working electrode, a platinum coil as the counter electrode, and a silver wire as a pseudo-reference electrode. When the CV experiments were complete, ferrocene was added to the cell as an internal standard. All the potential values in this study are expressed relative to the ferrocene/ferrocenium redox couple $\left(\mathrm{Fc} / \mathrm{Fc}^{+}\right)$, which exhibits oxidation potentials at $0.48 \mathrm{~V}$ (in DCE) and $0.38 \mathrm{~V}$ (in $\mathrm{MeCN}$ ) vs saturated calomel electrode (SCE). ${ }^{26}$ The working electrode was polished on a felt pad with $0.3 \mu \mathrm{m}$ alumina and then sonicated in water and absolute ethanol for $3 \mathrm{~min}$ each; it was then dried in an oven at $50{ }^{\circ} \mathrm{C}$. The IR drop was corrected using a positive feedback technique. Spectroelectrochemical experiments were performed using a homemade cell built from a commercial UV-vis cuvette. An ITO-coated glass (a piece that fit in the cuvette) was used as the working electrode, a platinum wire as the counter electrode, and an $\mathrm{Ag}$ wire as the pseudo-reference electrode. The cell was placed in the optical path of the sample light beam in a Hewlett-Packard 8453 diode array spectrophotometer. Background correction was performed by recording a UV-vis spectrum of a blank cell (an electrochemical cell with an ITO working electrode without the polymer film) under conditions and parameters identical to those used for the polymer experiment.

\section{Results and Discussion}

Synthesis. Scheme 1 illustrates the synthesis of $\mathbf{1}$, which began from the copper-catalyzed coupling ${ }^{27}$ of 2,7-dibromo9, $9^{\prime}$-spirobifluorene (2) with carbazole to give bromide $\mathbf{3}(54 \%)$. Suzuki coupling ${ }^{28}$ of pinacolatoborane 4 , which was synthesized from isophthalic ester ${ }^{29}$ in $86 \%$ yield through Pd-catalyzed coupling with bis(pinacolato)diboron, ${ }^{30}$ with the bromide $\mathbf{3}$ gave the diester $5(60 \%)$. The diester 5 was treated with hydrazine to generate the dihydrazide $6(95 \%)$, which was then reacted with the acid chloride $7^{31}$ to afford the bis(acylhydrazide) $\mathbf{8}$ (74\%). Heating 8 under reflux in phosphorus oxychloride for $12 \mathrm{~h}$ gave the desired target molecule 1 in $72 \%$ yield. A model compound $(\mathbf{9})^{32}$ was also synthesized for parallel studies.

Spectroscopic analysis of 1 through ${ }^{1} \mathrm{H}$ NMR and 2D-COSY experiments helped us to identify several characteristic signals that may be useful for the characterization of similar compounds. The doublet at $6.90(\mathrm{~J}=7 \mathrm{~Hz})$, belonging to $\mathrm{H}_{\mathrm{q}}$, is a unique feature of the spirobifluorene structure. The protons on the trisubstituted benzene appear at the lowest field $-\mathrm{H}_{\mathrm{c}}$ at $8.60(\mathrm{t}$, $J=1.6 \mathrm{~Hz})$ and $\mathrm{H}_{\mathrm{d}}$ at $8.36(\mathrm{~d}, J=1.6 \mathrm{~Hz})$ ppm-because of the presence of two electron-withdrawing oxadiazole substituents. The oxadiazole ring also causes the adjacent $\mathrm{H}_{\mathrm{e}}$ proton to resonate at a lower field $[7.93 \mathrm{ppm}(\mathrm{d}, J=9 \mathrm{~Hz})]$. In contrast, 

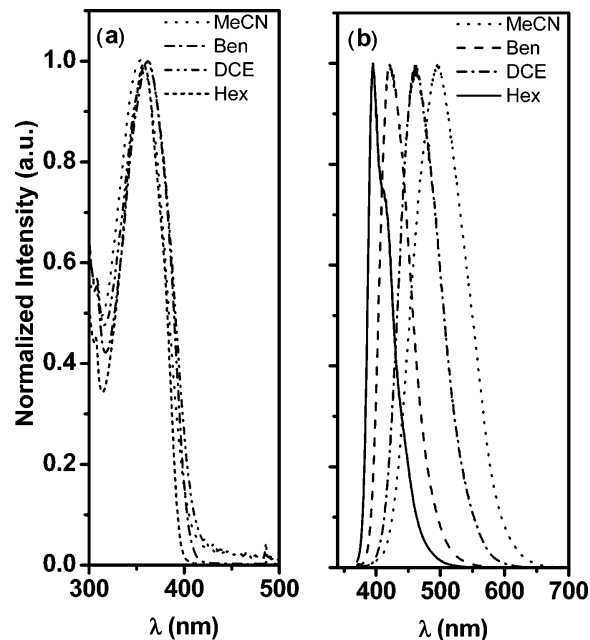

Figure 1. (a) Absorption and (b) photoluminescence spectra of $\mathbf{1}$ in various solvents $(\mathrm{MeCN}=$ acetonitrile; $\mathrm{Ben}=$ benzene; $\mathrm{DCE}=$ dichloroethane; Hex = hexane).

the electron-donating diphenylamino group causes the signal of the proton $\mathrm{H}_{\mathrm{f}}$ to appear upfield at $7.10 \mathrm{ppm}(\mathrm{d}, J=9 \mathrm{~Hz})$. Similarly, the presence of the carbazole moiety results in the adjacent proton $\mathrm{H}_{\mathrm{a}}$ residing at a unique upfield shift of 6.91 ppm $(\mathrm{d}, J=2 \mathrm{~Hz})$, whereas $\mathrm{H}_{\mathrm{g}}$ appears as a doublet of doublets at $7.59 \mathrm{ppm}(J=7 \mathrm{~Hz})$. The doublet for proton $\mathrm{H}_{\mathrm{h}}$, at 8.09 $\operatorname{ppm}(J=7 \mathrm{~Hz})$, is also very characteristic, as is the signal for proton $\mathrm{H}_{\mathrm{i}}$ at $8.03 \mathrm{ppm}(\mathrm{d}, J=7 \mathrm{~Hz})$. The two overlapping doublets of protons $\mathrm{H}_{\mathrm{m}}$ and $\mathrm{H}_{\mathrm{j}}$ appear clearly at $7.80 \mathrm{ppm}(\mathrm{J}=$ $7 \mathrm{~Hz})$ and $7.81 \mathrm{ppm}(J=7 \mathrm{~Hz})$, respectively.

Photophysical Characterization. Figure 1 depicts the dependence of the absorption and emission spectra of the $\mathrm{D}-\mathrm{A}$ molecule 1 on the solvent polarity. In general, in the absence of significant electronic interactions between $\mathrm{D}$ and A moieties in the ground state, the absorption spectrum of a D-A system displays the combined characteristics of the acceptor and donor chromophores ${ }^{16,17,33,34}$ and exhibits low sensitivity to the dielectric environment. Because 1 exhibited absorption behavior independent of the solvent polarity, we infer that the electronic interactions between TPA and OXD groups were negligible in the ground state. In contrast, the emission characteristics of the D-A molecule 1 revealed a strong solvatochromic effect; for example, the emission spectrum of $\mathbf{1}$ in hexane exhibits a maximum at $394 \mathrm{~nm}$, which was red-shifted significantly to 495 $\mathrm{nm}$ in a polar medium such as $\mathrm{MeCN}$. The apparent dependence of the emission wavelength of $\mathbf{1}$ on the solvent polarity is a strong indication of a photoinduced electron-transfer process, leading to a highly polarized excited-state with a large dipole moment.

Electrochemical Characterization. We undertook a study of the redox behavior of $\mathbf{1}$ using cyclic voltammetry (CV). Figure 2a displays the first CV scan of $\mathbf{1}$; we observe two oxidation processes: a clear shoulder at ca. $0.710 \mathrm{~V}$ and a peak at $0.850 \mathrm{~V}$. From the $\mathrm{CV}$ trace, we estimate that the first anodic process generated twice the current relative to that of the second one. ${ }^{35}$ It is known that TPA and CBZ moieties can be oxidized to the respective mono radical cations and that CBZ is oxidized at a potential higher than that of the structurally related TPA. ${ }^{20}$ Thus, we propose that the TPA groups of $\mathbf{1}$ are involved in the first oxidation process and the CBZ group is involved in the second oxidation process.

To gather sufficient information to support our hypothesis, we investigated the electrochemical characteristics of the model compound $\mathbf{9}$, which allowed us to shed light on the origin and

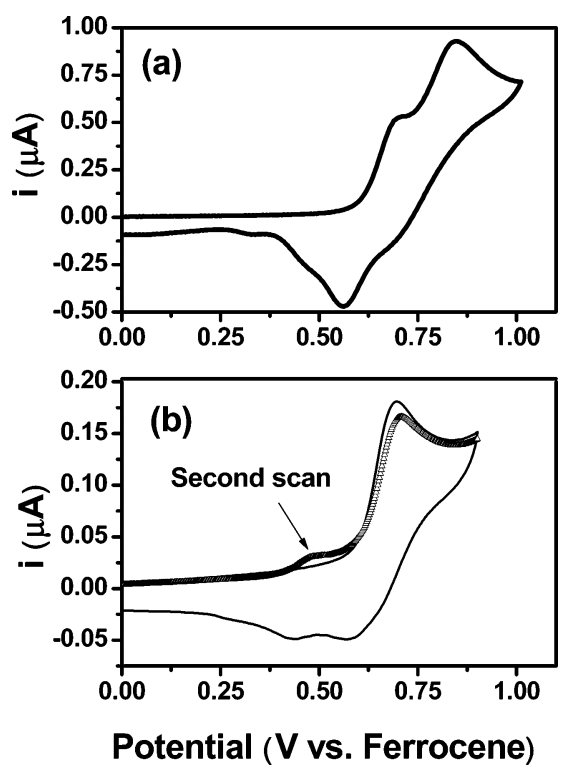

Figure 2. Cyclic voltammograms of (a) $\mathbf{1}(0.96 \mathrm{mM})$ and (b) $\mathbf{9}(0.142$ $\mathrm{mM})$. Supporting electrolyte: $0.1 \mathrm{M}$ TBAP in DCE; scan rate $(v)$ : 0.1 $\mathrm{V} \mathrm{s}{ }^{-1}$.

contribution of TPA in the oxidation processes occurring in $\mathbf{1}$. Because 9 contains only TPA and OXD moieties, we expected that only the TPA moieties would be oxidized in an oxidation process. Figure $2 \mathrm{~b}$ presents the first anodic scan of $\mathbf{9}$, obtained on a freshly polished Pt electrode. The CV scan exhibits an oxidation process at $0.706 \mathrm{~V}$-the same potential as the shoulder observed for 1 -which agrees with our preliminary assessment that the CV shoulder of $\mathbf{1}$ reflects oxidation of the TPA moieties. In the reverse scan, we did not observe any complementary reduction peaks in the spanned range of scan rates $(v ; 0.05<$ $\left.v<0.5 \mathrm{~V} \mathrm{~s}^{-1}\right)$. This behavior is typical of an irreversible chemical reaction coupled to the charge transfer. ${ }^{36-38}$ In this case, the homogeneous reaction gives a product that is detected as a new redox couple, with a reduction potential $\left(E_{\mathrm{pc}}\right)$ of 0.427 $\mathrm{V}$ in the reverse scan and an oxidation peak $\left(E_{\mathrm{pa}}\right)$ at $0.471 \mathrm{~V}$ in the second anodic scan (Figure 2b). The CV trace of 9 is in agreement with the behavior of a typical TPA oxidation..$^{10,11,13,16}$ The TPA oxidation produces a dimer (TPB) that possesses a more extended $\pi$-conjugation. As a consequence, TPB is easier to oxidize than the parent compound (TPA) ${ }^{39}$ Because the TPB molecule undergoes two oxidation processes at different potentials, in the case of $\mathbf{9}$, the newly formed redox couple could correspond to the first oxidation of TPB, as previously described, and the second one overlaps with the principal peak of $\mathbf{9 .}{ }^{11}$

The presence of the signals for TPB moieties in the second $\mathrm{CV}$ scan of 9 provides positive support for our expectation that, for 1, the two TPA substituents separated by OXD groups would act independently, rendering the electropolymerization process feasible. Consequently, we preformed repetitive CV analyses with $\mathbf{1}$, scanning between -0.6 and $+0.75 \mathrm{~V}$, where only the oxidation of TPA occurs (Figure 3a). The different scans obtained within this range of potentials produced a continuous growth of the current values - an indication that the TPA dimerization process was involved in the formation of a conducting film on the electrode surface. Furthermore, when repetitive $\mathrm{CV}$ experiments were performed using a solution of 9, we observed a growth pattern of the current values that was similar to that obtained using 1 (Figure $3 b$ ).

It is particularly interesting that we observed different electrochemical behavior when we performed the CV experiments of $\mathbf{1}$ with the scanning potentials switched to more anodic 

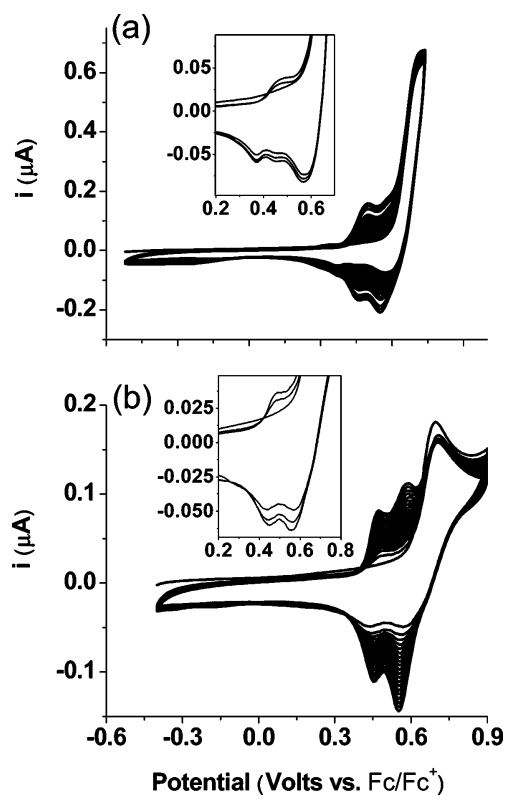

Figure 3. Repetitive cyclic voltammograms for the oxidation on a $\mathrm{Pt}$ electrode in DCE containing $0.1 \mathrm{M}$ TBAP of (a) a $0.83 \mathrm{mM}$ solution of $\mathbf{1}\left(v=0.075 \mathrm{~V} \mathrm{~s}^{-1}\right)$ and (b) a $0.14 \mathrm{mM}$ solution of $9(v=0.1 \mathrm{~V}$ $\mathrm{s}^{-1}$ ). The insets display the first, second, and third CV scans.

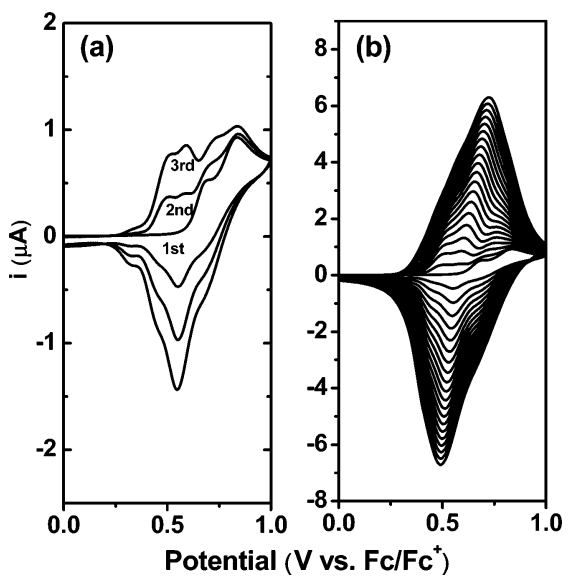

Figure 4. (a) First three consecutive CV scans of the oxidation on a Pt electrode of a $0.96 \mathrm{mM}$ solution of 1 in DCE containing $0.1 \mathrm{M}$ TBAP $\left(v=0.1 \mathrm{~V} \mathrm{~s}^{-1}\right)$. (b) Film development of 1 through repetitive CV.

values, where both TPA and CBZ oxidations occur (Figure 4a). Clearly, the growth of a new peak at $0.54 \mathrm{~V}$ is evident in the reverse scan; this signal was not observed when the CV scans were cycled between potentials where only the TPA moieties are oxidized (cf. insets of Figure 3a,b). We assign the new peak to the reduction of the carbazole dimer ${ }^{18-20}$ generated through oxidative coupling of carbazole radical cations. When multiple potential scans are applied to the electrode, we observed continuous increments of the current values (Figure $4 \mathrm{~b}$ ). This observation is a good indication that new polymeric products were gradually being deposited on the surface of the electrode, affording an electroactive film exhibiting good electrical conductivity. On the other hand, if we compare the rate of polymeric film development resulting from the formation of TPB moieties (Figure 3a) with those where the carbazole dimer is simultaneously involved in the polymerization process (Figure 4), we find that the latter situation is more efficient. This result is in agreement with the fact that, in general, the CBZ radical cation has coupling rate constants that are 4-5 orders of magnitude higher than those of the TPA group. ${ }^{20}$

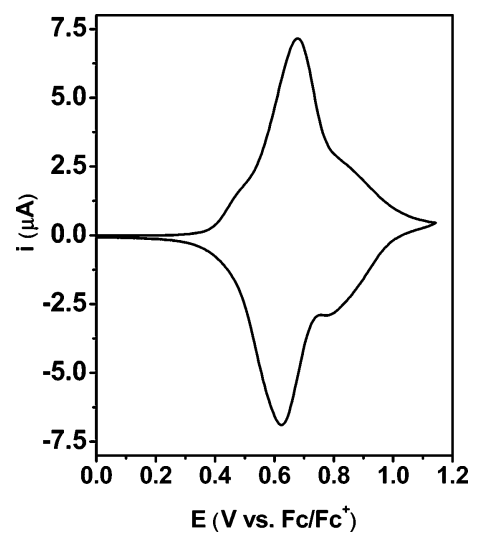

Figure 5. Cyclic voltammogram of the electrodeposited film derived from 1 on a Pt electrode in MeCN containing 0.1 M TBAP $(v=0.1$ $\mathrm{V} \mathrm{s}^{-1}$ ).

When we performed multiple CV scanning of a Pt electrode between 0.0 and $1.0 \mathrm{~V}$ in a solution containing 1 and then removed the electrode from the cell and transferred it to a $\mathbf{1}$-free electrolyte solution in $\mathrm{MeCN}$, the new cyclic voltammogram we obtained (Figure 5) displays stable electrochemical behavior. This finding confirms that the oxidation processes of $\mathbf{1}$ produce an irreversibly adsorbed product on the Pt electrode surface. The electrochemical response of the polymeric film remains unchanged after exposure to air and storage under ambient conditions for several weeks.

Proposed Structure of the Electrogenerated Film. The electrochemical analyses indicated the presence of both TPB groups and carbazole dimer groups in the resulting film structure. On the basis of this observation, we propose the polymer formation mechanism depicted in Scheme 2. The oxidation of $\mathbf{1}$ at lower potential (ca. $0.70 \mathrm{~V}$ ) provides two separated TPA radical cations that subsequently dimerize to generate TPB moieties, giving rise to a linear polymer (or oligomer). At higher potentials, oxidation of the carbazole moiety and concomitant dimerization at either the $\mathrm{C} 3$ or C6 positions then produces a cross-linked structure. Consequently, Scheme 2 illustrates a possible structure for the polymer prepared from 1 that agrees with the observed $\mathrm{CV}$ responses and that the continuous film growth led to films exhibiting superior conductivity. ${ }^{10,11,13,16,17,20}$

The electrogenerated film of $\mathbf{1}$ is a novel material that contains excellent charge transport groups-TPB and dicarbazoyl units - that have great potential for application as hole transporters. The OXD moieties not only play an important role in blocking electronic delocalization between the two terminal TPA groups but also exhibit the ability to transport electrons efficiently. Within the cross-linked polymer of $\mathbf{1}$ is embedded a rigid spirobifluorene skeleton, which is a good light-emitting center that can impart sufficient thermal and morphology stability, as well as emissive properties, to the film. All these characteristics result in the film prepared from 1 having great potential for use in optoelectronic systems and device applications, such as OLEDs, electrochromics, and solar energy conversion. 1,3,21,22,40

Spectroelectrochemical Characterization of the Electrogenerated Film. The observed formation of a stable and reproducible film through the electropolymerization of $\mathbf{1}$ on a Pt electrode prompted us to perform a UV-vis spectroelectrochemical analysis of it. A film suitable for spectral analysis was grown over an optically transparent indium tin oxide (ITO) electrode by cycling the potential between 0 and $1.0 \mathrm{~V}$. This procedure allowed us to obtain electronic absorption spectra 
Scheme 2
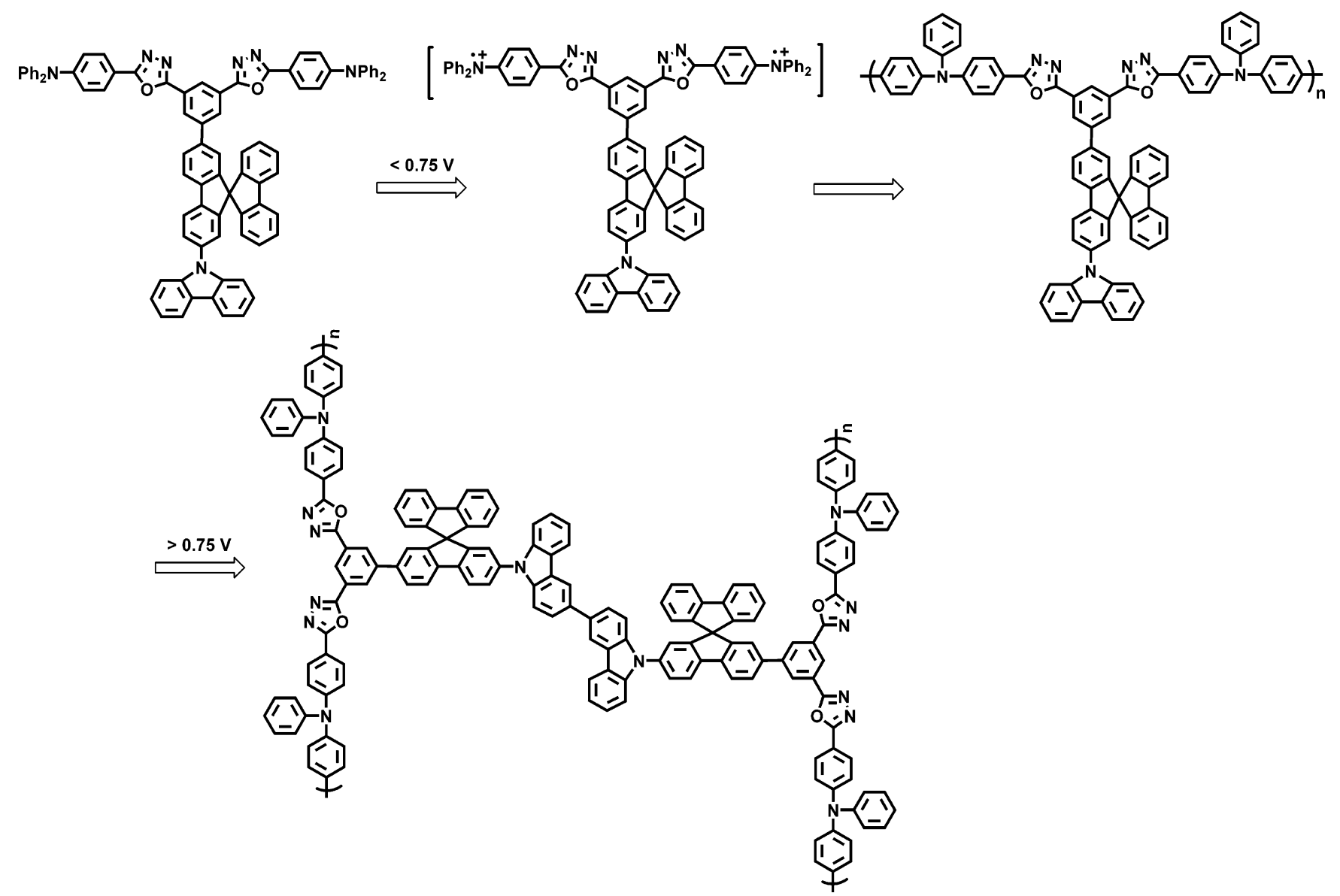

under potential control in a $0.1 \mathrm{M} \mathrm{TBAP} / \mathrm{MeCN}$ solution. In the neutral form, at $0 \mathrm{~V}$, the film exhibited strong absorption at wavelengths below $400 \mathrm{~nm}$, but it was almost transparent in the visible region. As the applied potential became more anodic, a broad band having its maximum absorption wavelength at $749 \mathrm{~nm}$ gradually increased in intensity (Figure 6a).

The presence of this band $(749 \mathrm{~nm})$ in the oxidized film agrees with the existence of TPB species in the polymeric

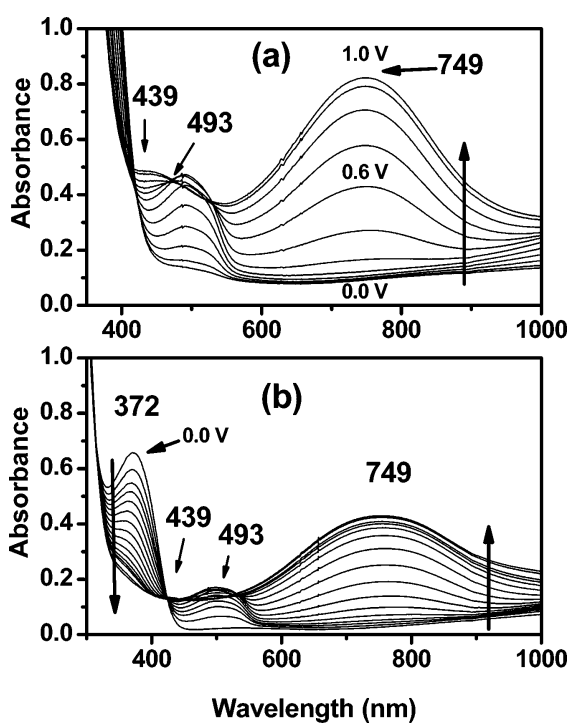

Figure 6. Absorption spectra of the electrodeposited films of (a) 1 and (b) 9 on an ITO electrode at various applied potentials in $\mathrm{MeCN}$ containing $0.1 \mathrm{M}$ TBAP. The arrows indicate the spectral changes as the applied potential became more anodic. structure. The oxidation of TPB produces dications that exhibit a broad absorption band centered at ca. $750 \mathrm{~nm}$, as we observed previously for a related system. ${ }^{16} \mathrm{We}$ note, however, that oxidized biscarbazole also display an absorption within the range 500-800 nm. ${ }^{41,42}$ Thus, we cannot exclude the contribution from the absorption of oxidized biscarbazole moieties from the longwavelength broad band observed at higher applied potentials. Moreover, the absorption peak centered at $439 \mathrm{~nm}$ (Figure 6a) also suggests the presence of biscarbazole units in the film structure. ${ }^{41}$ On the other hand, the intensity of the absorption band centered at $493 \mathrm{~nm}$ increased upon further oxidation of the film; it reached a maximum at applied potentials near 0.60 $\mathrm{V}$, decreasing subsequently at more anodic values. We attribute this peak to the formation of TPB radical cations, which are obtained as intermediates during the formation of TPB dications. ${ }^{10,16}$ Thus, our spectroelectrochemical analysis is, again, in agreement with the proposed structure of the film, i.e., where the dimerizations of both the TPA and carbazole moieties of 1 are involved in the electropolymerization process (Scheme 2). Additionally, a corresponding UV-vis spectroscopic study under potential control using the film formed through electrooxidation of $\mathbf{9}$ reconfirmed our proposed structure for the film of $\mathbf{1}$. As shown in Figure 6b, the development of bands at 493 and $749 \mathrm{~nm}$, due to the formation of TPB radical cations and dications, respectively, is clearly distinguished, together with the presence of an isosbestic point at $439 \mathrm{~nm}$, i.e., between the neutral $\left(\lambda_{\max }=372 \mathrm{~nm}\right)$ and oxidized forms of TPB. In the case of the film of $\mathbf{1}$, this isosbestic point is masked by the absorption developed by the oxidized biscarbazole at the same wavelength. ${ }^{41}$ The observed UV-vis absorption changes in the film of $\mathbf{1}$ at various applied potentials are fully reversible and 


\section{Electrochromism}

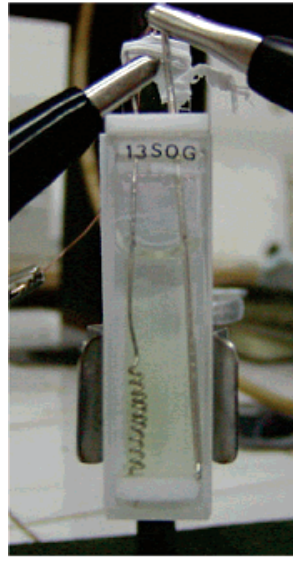

$0.00 \mathrm{~V}$
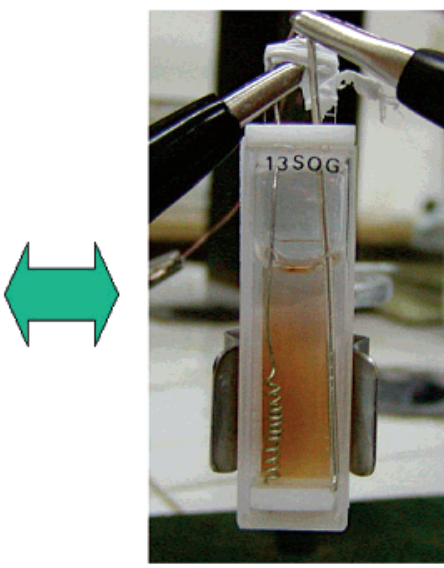

$0.60 \mathrm{~V}$

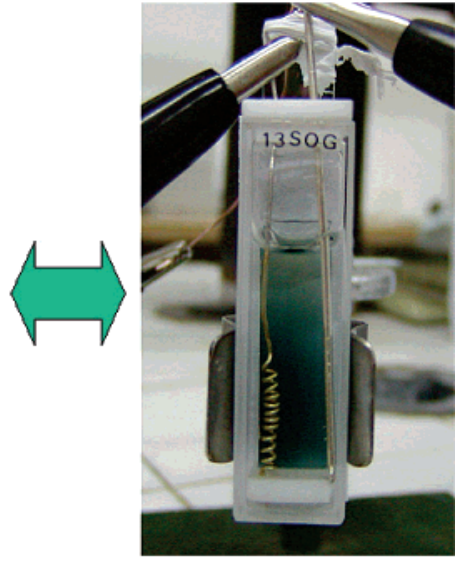

$0.90 \mathrm{~V}$

Figure 7. Photographic images of a film of $\mathbf{1}$ on an ITO electrode at various applied potentials.

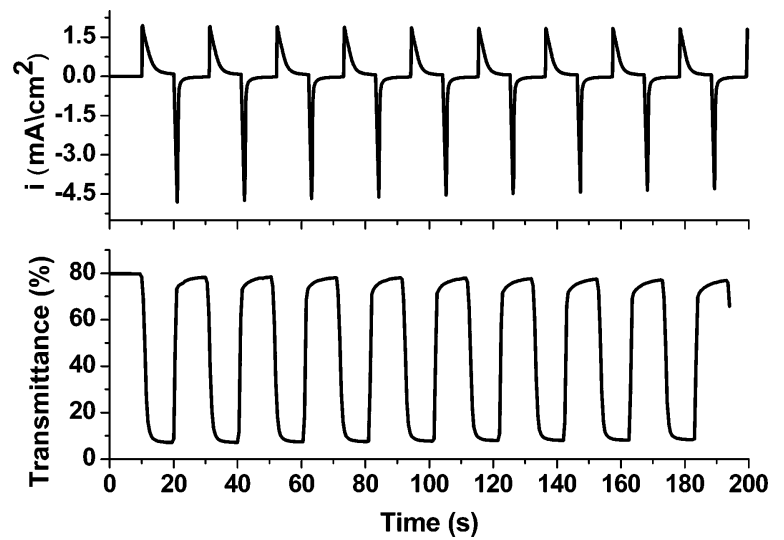

Figure 8. Dynamic changes of the transmittance and current upon switching the potential between 0 and $0.90 \mathrm{~V}$ with a pulse width of 10 $\mathrm{s}$ applied to the electrodeposited ITO/film of $\mathbf{1}$ in $\mathrm{MeCN}$ containing $0.1 \mathrm{M}$ TBAP. The absorption was recorded at $749 \mathrm{~nm}$.

are associated with significant color changes - indeed, they even can be seen readily by the naked eye. Thus, we next conducted a study on the electrochromic capabilities of the new material. Figure 7 displays photographic images, recorded under ambient conditions, of the film in its neutral [applied potential $\left(E_{\text {app }}\right)=$ $0 \mathrm{~V}]$, semioxidized $\left(E_{\text {app }}=0.60 \mathrm{~V}\right)$, and fully oxidized $\left(E_{\text {app }}=\right.$ $0.90 \mathrm{~V}$ ) states. The film colorations (transparent/pale yellow, orange, and blue, respectively) are distributed homogenously across the ITO electrode surface and survive for more than hundreds of oxidation/reduction cycles.

We extracted the electrochromic parameters of the film of $\mathbf{1}$ from an analysis of the absorbance change at $749 \mathrm{~nm}$ with respect to time while the potential was step-switched between the neutral and oxidized states $\left(E_{\text {app }}=0\right.$ and $\left.0.90 \mathrm{~V}\right)$. As indicated in Figure 8, the changes in the absorbance at $749 \mathrm{~nm}$ reflect the switch in current, and the kinetics of the charge transport process can be referenced to the coloration response time.

The times required for $90 \%$ full transmittance changes at 749 $\mathrm{nm}$ were $1.4 \mathrm{~s}$ for the coloration step and $1.0 \mathrm{~s}$ for the bleaching step, reflecting the different conductivities between the reduced and oxidized forms of the film of $\mathbf{1}$. The amount of charge $(Q)$ interchanged in the oxidation/reduction steps were similar, however, and the value was used to estimate the coloration efficiency $[\eta=\Delta A(\lambda) / Q] .{ }^{43}$ Here, $Q$ is the injected charge per unit electrode area $\left(\mathrm{C} / \mathrm{cm}^{2}\right)$ and $\Delta A$ is the change in absorbance during a redox step of the device. The blue coloration efficiency (ca. $-200 \mathrm{C}^{-1} \mathrm{~cm}^{2}$ ) is comparable to that obtained in related materials. ${ }^{16}$ In addition, the film prepared from 1 exhibits a high contrast ratio: the transmittances of 79.2 and $7.3 \%$ in the neutral and fully oxidized states, respectively, provide a difference ( $\Delta \% T$ ) between those states of $71.9 \%$. Taken together, these results suggest that the films of electropolymerized 1 exhibit highly promising electrochromic characteristics under aerobic conditions.

Conclusion. Herein, we synthesized and characterized a novel D-A chromophore composed of two electropolymerizable sites (TPA and CBZ) configured through a rigid spirobifluorene core. The introduction of 1,3,4-oxadiazole (OXD) units as electronwithdrawing moieties suppresses the delocalization of TPA radical cations effectively, allowing efficient electropolymerization through feasible TPA dimerization. The electropolymerization of the TPA groups in $\mathbf{1}$ at potentials below $0.70 \mathrm{~V}$ was confirmed through a comparative study of the model compound 9 and through spectroelectrochemical characterization of the films prepared from 1. The presence of a second oxidizable group (CBZ) in $\mathbf{1}$ gives rise to efficient cross-linkage in the electrogenerated polymeric films at higher oxidation potentials $(>0.70 \mathrm{~V})$. These polymer films exhibit reversible electrochemical oxidation-accompanied by strong color changes having a high coloration efficiency and contrast ratio-that can be switched through modulation of the applied potential. Together, these characteristics suggest that this new type of polymer has great potential for use in optoelectronics applications.

Acknowledgment. This study was supported financially by the National Science Council of Taiwan. We are grateful to Consejo Nacional de Investigaciones Científicas y Técnicas (CONICET-Argentina), Agencia Nacional de Promoción Científica y Tecnológica (ANPCYT-Argentina), Secretaría de Ciencia y Técnica de la Universidad Nacional de Río Cuarto (SECYT-UNRC), and Fundación Antorchas for financial support. L.O. and F.F. are scientific members of CONICET.

\section{References and Notes}

(1) Thelakkat, M. Macromol. Mater. Eng. 2002, 287, 442.

(2) Drobizhev, M.; Karotki, A.; Dzenis, Y.; Rebane, A.; Suo, Z. Y.; Spangler, C. W. J. Phys. Chem. B 2003, 107, 7540. 
(3) Hughes, G.; Bryce, M. R. J. Mater. Chem. 2005, 15, 94.

(4) Friend, R. H.; Gymer, R. W.; Holmes, A. B.; Burroughes, J. H.; Marks, R. N.; Taliani, C.; Bradley, D. D. C.; Dos Santos, D. A.; Bredas, J. L.; Logdlund, M.; Salaneck, W. R. Nature (London) 1999, 397, 121

(5) Noh, Y.-Y.; Azumi, R.; Goto, M.; Jung, B.-J.; Lim, E.; Shim, H.-K.; Yoshida, Y.; Yase, K.; Kim, D.-Y. Chem. Mater. 2005, 17, 3861.

(6) Spehr, T.; Pudzich, R.; Fuhrmann, T.; Salbeck, J. Org. Electron. $\mathbf{2 0 0 3}, 4,61$.

(7) Katsis, D.; Geng, Y. H.; Ou, J. J.; Culligan, S. W.; Trajkovska, A.; Chen, S. H.; Rothberg, L. J. Chem. Mater. 2002, 14, 1332

(8) Geng, Y.; Katsis, D.; Culligan, S. W.; Ou, J. J.; Chen, S. H.; Rothberg, L. J. Chem. Mater. 2002, 14, 463.

(9) Wong, K.-T.; Chien, Y.-Y.; Chen, R.-T.; Wang, C.-F.; Lin, Y.-T.; Chiang, H.-H.; Hsieh, P.-Y.; Wu, C.-C.; Chou, C. H.; Su, Y. O.; Lee, G.-H.; Peng, S.-M. J. Am. Chem. Soc. 2002, 124, 11576.

(10) Oyama, M.; Nozaki, K.; Okazaki, S. Anal. Chem. 1991, 63, 1387.

(11) Seo, E. T.; Nelson, R. F.; Fritsch, J. M.; Marcoux, L. S.; Leedy, D. W.; Adams, R. N. J. Am. Chem. Soc. 1966, 88, 3498.

(12) Creason, S. C.; Wheeler, J.; Nelson, R. F. J. Org. Chem. 1972, 37, 4440.

(13) Zhang, T.; Toth, B. Anal. Chem. 2000, 72, 2533.

(14) Creason, S. C.; Wheeler, J.; Nelson, R. F. J. Org. Chem. 1972, 37, 4440.

(15) Leung, M.-K.; Chou, M.-Y.; Su, Y.-O.; Chiang, C.-L.; Chen, H.-L.; Yang, C.-F.; Yang, C.-C.; Lin, C.-C.; Chen, H.-T. Org. Lett. 2003, 5, 839.

(16) Otero, L.; Sereno, L.; Fungo, F.; Liao, Y.-L.; Lin, C.-Y.; Wong, K.T. Chem. Mater. 2006, 18, 3495.

(17) Kamtekar, K. T.; Wang, C.; Bettington, S.; Batsanov, A. S.; Perepichka, I. F.; Bryce, M. R.; Ahn, J. H.; Rabinal, M.; Petty, M. C. J. Mater. Chem. 2006, 16, 3823.

(18) Morin, J.-F.; Leclerc, M.; Ade, D.; Siove, A. Macromol. Rapid Commun. 2005, 26, 761 .

(19) Ambrose, J. F.; Nelson, R. F. J. Electrochem. Soc. Electrochem. Sci. 1967, 115, 1159

(20) Ambrose, J. F.; Carpenter, L. L.; Nelson, R. F. J. Electrochem. Soc. Electrochem. Sci. Technol. 1975, 122, 876.

(21) Kulkarni, A. P.; Tonzola, C. J.; Babel, A.; Jenekhe, S. A. Chem. Mater. 2004, 16, 4556.
(22) Mitschke, U.; Bauerle, P. J. Mater. Chem. 2000, 10, 1471.

(23) Justin Thomas, K. R.; Lin, J. T.; Tao, Y.-T.; Ko, C.-W. J. Am. Chem. Soc. 2001, 123, 9404.

(24) Ko, C.-W.; Tao, Y.-T.; Lin, J. T.; Justin Thomas, K. R. Chem. Mater. 2002, 14, 357

(25) Ma, L. H.; Chen, Z. B.; Jiang, Y. B. Chem. Phys. Lett. 2003, 372, 104.

(26) Connelly, N. G.; Geiger, W. E. Chem. Rev. 1996, 96, 877.

(27) Klapars, A.; Antilla, J. C.; Huang, X.; Buchwald, S. L. J. Am. Chem. Soc. 2001, 123, 7727.

(28) Cossy, J.; Belotti, D. J. Org. Chem. 1997, 62, 7900.

(29) Brunner, H.; Janura, M.; Stefaniak, S. Synthesis 1998, 45, 1742.

(30) Ishiyama, T.; Murata, M.; Miyaura, N. J. Org. Chem. 1995, 60, 7508.

(31) Wilkerson, W. W.; Akamike, E.; Cheatham, W. W.; Hollis, A. Y.; Collins, R. D.; DeLucca, I.; Lam, P. Y. S.; Ru, Y. J. Med. Chem. 1996, 39, 4299 .

(32) Tamoto, N.; Adachi, C.; Nagai, K. Chem. Mater. 1997, 9, 1077.

(33) Fungo, F.; Wong, K. T.; Ku, S.-Y.; Hung, Y.-Y.; Bard, A. J. J. Phys. Chem. B 2005, 109, 3984.

(34) Jenekhe, S. A.; Lu, L.; Alam, M. M. Macromolecules 2001, 34, 7315.

(35) Bard, A. J.; Faulkner, L. R. Electrochemical Methods-Fundamentals and Applications; John Wiley \& Sons: New York, 1980.

(36) Nicholson, R. S.; Shain, I. Anal. Chem. 1964, 36, 706.

(37) Nicholson, R. S.; Shain, I. Anal. Chem. 1965, 37, 178.

(38) Mastragostino, M.; Nadjo, L.; Saveant, J. M. Electrochim. Acta 1968, 13,721 .

(39) Vettorazzi, N.; Silber, J. J.; Sereno, L. J. Electroanal. Chem. 1981, $125,459$.

(40) Bach, U.; Lupo, D.; Comte, P.; Moser, J. E.; Weissörtel, F.; Salbeck, J.; Spreitzer, H.; Grätzel, M. Nature (London) 1998, 395, 583

(41) Marrec, P.; Dano, C.; Gueguen-Simonet, N.; Simonet, J. Synth. Met. 1997, 89, 171

(42) Yavuz, O.; Sezer, E.; Sarac, A. S. Polym. Int. 2001, 50, 271.

(43) Monk, P. M. S.; Mortimer, R. J.; Rosseinsky, D. R. Electrochromism: Fundamentals and Applications; VCH: Weinheim, 1995.

MA070055M 